\title{
Introduction
}

\author{
Helen Irving
}

The idea that a country's constitution is 'gendered' - having a disparate or differential impact upon women and men - challenges traditional views of constitutions and constitutionalism. It is, however, not new. It was expressed, indirectly, by the 'Founding Mothers' of the United States (De Pauw 1975; Norton 1996; Roberts 2004) and in the French Revolution (Elson-Roessler 1996; Heuer 2005). It was recognized by American women who protested against the reference to voting rights for male citizens alone in the Fourteenth Amendment of the United States Constitution (1868) (Morais 1988), and then against the wording of the Fifteenth Amendment (1870) that prohibits denial of the franchise only on grounds of race. It was understood by women who campaigned for or against the federation of the Australian colonies in the 1890s and those who petitioned for women's rights to be included in the new Australian Constitution (Irving 1999). It was asserted by American women who (unsuccessfully) brought constitutional challenges to laws that excluded women from voting, as well as from certain professions. ${ }^{1}$ It was understood by those who campaigned for the constitutional entrenchment of temperance, including in the United States ratification of the Eighteenth Amendment in 1919 and its subsequent repeal in 1933 (Rose 1996). It was at the heart of the campaign for an Equal Rights Amendment to the US Constitution which began in 1923 and continued, unabated, until its defeat in 1982. It was affirmed by the 'Famous Five' in 1929 who successfully challenged the interpretation of Canada's 1867 constitution (the British North America Act) as excluding women from serving as Senators in the Canadian parliament (Sharpe and McMahon 2007). Many other early examples could be added.

Women's participation in constitutional ratification is also not new. Enfranchised women have voted in elections in their country for constituent assemblies, in referendums on the adoption of constitutions, and in other constitutional processes engaging the electorate. Indeed, as early as 1897, women in South Australia voted, along with men, for delegates to the convention at which the Australian Constitution was to be written 


\section{Constitutions and gender}

and, soon after, were joined by women from Western Australia in the referendums that approved the completed Constitution at the end of that decade.

Women's direct involvement in constitution-writing was certainly rare in the past, but is not unprecedented either. British Middle East expert, Gertrude Bell, played an important, if backstage, role in shaping the first constitution for Iraq in 1920; seven women were chosen for the Burmese Constituent Assembly in 1947 (Aung and Williams 2011); one woman served on a committee of the Constituent Assembly that framed the Japanese Constitution in 1946 (Gordon 2001); four women sat on the convention that framed the West German Basic Law in 1949 (Markovits 2008). No doubt there are other examples.

The modern understanding that constitutions are not neutral with respect to sex or gender was thus not without foundation when it first took root in the last decades of the twentieth century, but it was poorly recognized, and, with some few exceptions (for example, Amar 1995), the history was little known outside feminist historians' circles, and the insights it generated were neglected in the broader literature on constitution-making, spectacularly so in the literature on constitutionalism. ${ }^{2}$ The idea that constitutions are gendered began to (re-)emerge in the 'liberationist' era of the 1970s, when feminists challenged traditional gender roles and exposed systemic discrimination against women. The gendered character of the law was an inevitable target, and constitutional jurisprudence attracted attention.

Ruth Bader Ginsburg's 'Gender and the Constitution' (Ginsburg 1975), written 18 years before her appointment as Justice of the United States Supreme Court, reflected on the Court's then recent shift in reasoning. Having previously upheld discriminatory laws that were built on gendered stereotypes, the Court had now begun to extend the US Constitution's 'equal protection of the laws' to gender equality, beginning with the landmark case of Reed $v$ Reed $^{3}$ (in which a state law that gave men priority over women as executors of intestate estates was ruled unconstitutional). Other cases followed, furthering an understanding that constitutional interpretation is not neutral with regard to gender (even of apparently neutral constitutional provisions), and constitutional equality cannot be genuine if its protection replicates gender-based preconceptions of inequality. American feminists began to explore these cases as part of a wider analysis of women's status under the US Constitution, contributing to an emerging feminist theory of constitutionalism (Schwarzenbach and Smith 2003).

The idea of constitutionalizing women's equality by imagining how rights might be expressed by a 'hypothetical set of feminist drafters' of 
an entirely new constitution (Sullivan 2002) pushed this thinking further. Such understandings were, furthermore, applicable to other countries' constitutional systems. Comparative jurisprudence was prompted; systematic scholarship, however, took some years to flourish. In 2005, an edited volume (Baines and Rubio-Marín 2005) made a pioneering contribution to the field, with a study of gender and constitutional jurisprudence in multiple countries. The associated importance of approaches to constitutional interpretation was recognized (Jackson 2009). Such works focused closely on jurisprudence and case law, specifically on the way in which courts have (or have not) applied constitutional equality provisions to the protection or promotion of women's equality.

A right to equality can now be found in almost all modern democratic constitutions (O'Regan and Friedman 2011: 473), and it extends in many to an express provision for, or recognition of, gender equality. Indeed, '[o]f 194 written constitutions around the world ... almost two-thirds entrench equality or non-discrimination guarantees on the basis of sex, and almost one-third make express reference to gender' (Young 2016: 1). In the midst of the 'worldwide sweep' of gender equality laws, the question remains: how much real change has been generated (Young 2016: 3)?

The recognition that constitutional equality provisions, alone, do not guarantee equality in practice, has offered a prompt for thinking more broadly about the sources of inequality. The early exploration of gendered jurisprudence served thus as a catalyst for reflecting further on how a constitution's provisions were more widely 'gendered' and, from there, to questions about the choices that were made and the goals served by those who designed the provisions. The more fully the sources of inequality are understood, the more light is thrown on the fact that constitutions are limited in their capacity to effect equality. There are multiple social, economic, and demographic sources of women's disadvantage, most of which are beyond the direct reach of courts. Formal constitutional provisions for equality, furthermore, may not assist and, in some cases, will clash with measures designed to achieve substantive equality. There are differing perspectives on which should be prioritized, and on how, if at all, these tensions may be reconciled. But, scholars and practitioners alike still agree that legal and non-legal dimensions of inequality are interconnected, and that constitutions that have the purpose of serving equality are, at the very least, preferable to constitutions that do not. 
In countries where constitutional reform began in the 'postliberationist' era, these understandings had already emerged in engagement and practice. Feminist 'guides' to constitutional provisions started to appear (Brodsky and Day 1989; Smith and Wachtel 1992; Liebenberg 1995), as did accounts of women's role in new constitution-making in the 1980s and 1990s (Kome 1983; Dobrowolsky and Hart 2003). Comparative surveys of constitutional gender equality rights and provisions (including in preambles or founding principles) that recognize women also appeared (Van der Leest 2007). The theory of 'new constitutionalism', which demanded public and open participation in constitutionmaking and reform (Blount 2011), was put into practice in many countries, as new constitutions flourished in the post-Soviet era and post-apartheid South Africa, among other sites of dramatic shifts in power. The idea that constitutional design, as such, is gendered attracted attention (Sullivan 2002; Monopoli 2006; Irving 2008). This idea embraced both a 'holistic' or organic analysis, and also a focus on particular constitutional design choices, including constitutional federalism (Resnik 2002; Goldfarb 2003).

In the last few years (at the time of writing), the landscape appears to have moved towards normalization of the 'woman question' regarding constitutions and constitutionalism. This move has been recorded in practice around the world, and the subject of gender equality has become virtually routine in constitution-making; as noted, it is now reflected in many constitutions. A growing companion literature on constitutional design as a practical art has begun to appear. Online forums and databases now serve or acknowledge the gendered dimension of constitutions. UN Women has created a 'Global Gender Equality Constitutional Database', offering a 'repository of gender equality related provisions in 195 constitutions from around the world'. 'Constitute', 5 a comparative database of the world's constitutions that allows users to 'systematically compare [constitutions] across a broad set of topics', recognizes 'gender' and 'women' (including 'equality regardless of gender'; 'provision for matrimonial equality', and quotas for women's representation in national legislatures) in its search terms.

Guidelines for incorporating gender equality in constitutions under construction and for 'assessing' its recognition in existing constitutions have been developed by international agencies, NGOs and others. As Christina Murray and Cindy Wittke explain in Chapter 4 of this Handbook, the United Nations and the United Nations Development Program have embraced gender equality principles in their 'Guidance Notes' on constitution-making. In Chapter 7, a practitioner in the field, Melanie Allen, describes the creation of a 'Constitution Assessment for Women's 
Equality' toolkit by the Constitution Building Program of International IDEA, an intergovernmental organization that 'supports sustainable democracy worldwide'. ${ }^{6}$ In 2016, an 'ABC for a Gender Sensitive Constitution' was drafted under the auspices of Euromed Feminist Initiative IFE-EFI, with funding from the European Union and the Swedish Government (its co-author, Silvia Suteu, is the author of Chapter 1 of this Handbook). Such initiatives can be seen as the product of a new paradigm, a new way of thinking about constitutions, that envisages public participation and open-ended debate, among other measures, as critical to legitimate constitution-making, and accordingly embraces women's participation and equality aspirations.

The shift can also be observed in academic writing. Although the field remains largely specialized, general scholarly works on constitutionmaking and design are likely (although not invariably) to include at least an index reference to women and/or gender. ${ }^{7}$ Several international journals on constitutional law and constitutionalism can be found and, although none is yet dedicated to the topic of constitutions and gender/ sex/women, articles on the subject have appeared in recent years. A new journal, devoted specifically to constitutional design was launched in 2016; among the very first of its articles was an account of women's involvement in the democracy project in Burma. ${ }^{8}$

The shift, most agreeably, has also been registered in the subject of this Handbook. The Edward Elgar Research Handbooks in Comparative Law series includes a wide range of constitutional law sub-fields; its extension into gender and constitutions is a welcome and revealing development. This is, indeed, the first handbook (or encyclopaedia or 'companion') devoted specifically to the subject. The range of chapter topics reveals the multiple issues and perspectives it embraces, and also the complexity of thinking about constitutions in gendered terms, going well beyond equality rights, let alone simple claims of 'identity politics'.

Opening the Handbook, in Part I, 'Constitution-Making', the first two chapters capture the advantage of women's participation in constitutionmaking and constitutional recognition, as well as offering words of caution against romanticizing or overstating what participation can deliver. Silvia Suteu (Chapter 1) describes the involvement of women in constitutional referendums, conventions and constituent assemblies in Scotland, Ireland and Tunisia, and raises larger questions about the mobilization and activism of women and women's groups, with reflections on both the successes and the failures. She considers whether participatory constitution-making is, in practice, a plus for women and gender equality. Determining success, she writes, is 'more complex than might initially appear', and she warns against assuming that participation 
will deliver progressive outcomes, but concludes more positively that careful design of processes and 'comparative learning' from previous experience can be harnessed to increase the likelihood that participation will empower rather than 'fetter women as agents of constitutional change'.

Catherine Albertyn follows, in Chapter 2, with a rich account of constitution-making in South Africa in the early 1990s, an example both in the participatory processes and in the outcome - that has inspired women in many countries and has widely influenced constitution-making practice. The role of women in making the South African Constitution (1996) was both unprecedented and inspirational; women, Albertyn observes, achieved unprecedented representation in the post-apartheid constitutional state, as well as important recognition and rights protection in the text of the Constitution. At the same time, as she explains, the record reveals limits in constitutional commitments in addressing the deep-seated socio-economic inequalities and disadvantages experienced by women.

Johanna Bond, in Chapter 3, examines the clashes between constitutional equality provisions and customary laws in post-colonial countries in Sub-Saharan Africa. Bond explores the colonial history that 'set the stage' for the insertion of exclusionary clauses in post-independence constitutions in which gender equality rights were exempted from applying to the 'private' sphere of family and customary law, as well as later constitutional reform efforts to remove such exclusions and constitutional judgments that have resulted in overcoming them.

Christina Murray and Cindy Wittke, in Chapter 4, describe the growing engagement of the international community both in advising on constitution-making in practice and in promoting gender equality as a normative commitment. Although, as they emphasize, international agency involvement is generally restricted to offering support and guidance on constitutional options, they conclude that it is "now probably true to say that no process of substantial constitutional review in a democracy or emerging democracy can avoid engaging with gender issues'. The international community, they observe, has contributed to this shift and, in doing so, has strengthened women's equality claims and provided legitimacy for constitutionalizing gender justice.

Part II, 'Constitutional Design', begins with Wendy Lacey's discussion (Chapter 5) of the incorporation of international gender equality commitments in national constitutions. Lacey describes the various ways in which the UN Convention on the Elimination of All Forms of Discrimination Against Women (CEDAW) has been constitutionalized in different countries, and the protection of women's rights is found in other 
conventions, including the International Covenant on Civil and Political Rights (ICCPR) and the International Covenant on Economic, Social and Cultural Rights (ICESCR). Lacey also acknowledges that many countries have lodged reservations to CEDAW, with the effect, in many cases, of bracketing out family and marriage law from gender equality rights. She then turns to the rights of older persons, an issue of particular and growing importance for women, and one that is, she argues, inadequately accommodated in international law. Lacey considers the Brazilian Constitution's inclusion of the duty of the family, society and the state to assist the elderly, including to ensure their participation in the community. She then compares Brazil with Australia (both countries having compulsory voting laws) and notes the weaker protection offered in Australia for older voters' participation in political and constitutional voting. The incorporation of human rights in constitutions, she concludes, is only one manner of guaranteeing gender equality, and must be considered in its wider legal, social, political and cultural context.

Jill Vickers, in Chapter 6, offers a multifaceted reading of the relationship between constitutional federalism and gender. Vickers considers patterns of political representation and the distribution of family law in federal systems, and compares the advantages and disadvantages of localism and centralism, including for women members of cultural or sexuality minorities. The chapter then considers constitutional gender equality provisions in federal constitutions and design challenges posed by pluralism and constitutional divisions of power. Fiscal federalism is identified as particularly important to women, since the level at which social welfare programmes are offered will significantly affect women's circumstances and power. Vickers identifies new research questions and methods of research for this field, with potential for new insights about the impact of the distribution of powers and competences in federal systems.

In Chapter 7, Melanie Allen reminds us that constitution-making entails real-world design choices and that the constitutionalization of gender equality requires implementation skills and contextual institutional and cultural knowledge. Allen outlines the development of the 'Constitution Assessment for Women's Equality' tool and its trial in Nepal and Tunisia and Myanmar/Burma. As she explains, the Assessment is designed to bridge research and practice, and is expressed in the form of questions that help analyse the language and provisions of an existing or draft constitution from the perspective of women's equality, as well as help understand related equality issues that can be addressed institutionally, compare how other countries have addressed these, and identify and prioritize critical equality issues for advocacy in the relevant country. The Assessment, Allen explains, is not designed to guide the actual 
constitution-making process or specific channels of advocacy, and the country trials, we learn, have revealed the limitations and constraints of its global approach. Nevertheless, Allen concludes, the Assessment offers a step towards understanding 'the conditions that allow words on a [constitution's] page to flourish as lived reality'.

Opening Part III, 'Constitutional Practice', Vicki Jackson (Chapter 8) discusses the critical question of judicial interpretation of constitutional commitments to gender equality, highlighting that constitutional provisions do not self-activate but are subject to interpretation. Jackson identifies general interpretive principles that she believes most feminists can share, and illustrates interpretative practices through a comparison of case law in several countries, concluding that, while no single interpretive method is most likely to promote gender equality, a multi-valenced approach, open to a wide range of perspectives and values, may serve 'the dynamic, ongoing projects of equality'.

In Chapter 9, Susan Millns explores the role and evolution of the European Union (EU) in addressing and promoting gender equality, and considers its core 'constitutional' values and fundamental rights in the jurisprudence of the Court of Justice of the European Union, and in the EU's relationship with the European Convention on Human Rights. Millns explores how the original 'common market's' (European Economic Community's) model of free economic exchange has evolved into a broader model of European citizenship and non-discrimination, while still often failing to acknowledge the particular role and contribution of women. Much progress has been made, she observes, in the 'constitutionalization' of gender equality through the EU's Charter of Fundamental Rights, among others, but much remains to be done to achieve these commitments. The future for British women is now uncertain, too, with the UK's 2016 'Brexit' decision to leave the EU; the rights and freedoms in employment and education mobility that British women gained through the EU are now insecure. This development serves, she concludes, as a reminder of the fragility of such rights and their contingent character.

Dia Anagnostou, in Chapter 10, describes the constitutionalization of equality, including gender equality, in post-war European constitutions, and the battle between (prevalent) principles of formal equality and the recognition of substantive equality. Anagnostou explores legal and social mobilization for constitutional reform in Belgium, France, Germany and Greece, and in the international and supranational levels, including the European Union. She points out that gender equality provisions in constitutions remain controversial, and are often narrowly interpreted by courts, with provisions for substantive and positive action coexisting 
uneasily with formal equality principles. More research is needed, she reminds us, on whether constitutional provision for substantive equality can play a role in triggering change, but she concludes (drawing on the work of American constitutional scholar, Reva Siegel) with an affirmation of the importance of the constitutional text in non-juridical communication of understandings about gender equality and women's rights.

In Chapter 11, Beverley Baines explores the role of women judges in constitutional courts, asking the provocative question first posed by United States Supreme Court Justice, Ruth Bader Ginsburg: 'Why not nine women?' - in other words, why shouldn't a constitutional court be composed only of women judges? Baines addresses this question through an exploration of the 'strategy of containment' that underlies both 'parity' and 'feminist' proposals for increasing the number of women on courts, and explains how Ginsburg's proposal moves beyond this strategy. She illustrates her analysis with examples of constitutional decisions by women judges in several countries, and invites us to take the proposal for an all-woman court seriously. We have neither hypotheses nor answers to the many questions this proposal will generate, she concludes, but the legacy of women jurists suggests that constitutional justice for both women and men will be promoted.

Part IV, 'Constitutions and Citizenship', begins with a discussion by Ruth Rubio-Marín (Chapter 12) of the progress of women's political rights in Europe since the Second World War and of their progressive constitutionalization, most recently with the introduction of gender quotas for representation in legislatures and political offices. Arguments for women's equal participation in political decision-making, embraced in the United Nations Fourth World Conference on Women in 1995, she explains, generated mobilization by women's groups and leaders across Europe, and constitutional and legislative quotas were adopted in many European countries. At the same time, these developments have been contested, both politically and on constitutional grounds, as a breach of principles of formal equality. Nevertheless, Rubio-Marín explains, a renewed conception of women's citizenship has been generated through constitutional reforms and, in some cases, judicial interpretation, challenging a simple commitment to formal equality. The understanding that democratic legitimacy is jeopardized by women's political underrepresentation has triumphed, Rubio-Marín concludes. Women's equal citizenship still remains an 'unfinished project', but the proliferation of gender quotas in both political and civil society across Europe indicates a 'decisive move' towards its achievement.

In Chapter 13, Megan Davis considers the constitutional recognition of Indigenous peoples, both as achieved (in Canada and South Africa) and 
as advocated (in Australia), and she asks how it impacts, or is likely to impact, specifically on Indigenous women. Davis describes the legal recognition of Indigenous and customary law in the past as a product significantly of non-Indigenous anthropological observations that privileged the leadership roles of Indigenous men. She explores both the constitutional impact of early treaty-making between Indigenous peoples and non-Indigenous authorities and the emergence of an international law right to Indigenous self-determination which, she observes, is mostly silent on the position of women, and provides little guidance on, or provision for, Indigenous women's equal participation in decisionmaking or resolving the antagonism between women's rights as individuals and collective rights (exemplified in cases concerning customary marriage and domestic relations). Davis concludes, nevertheless, that recognition allows for a greater understanding of the way in which gender and race intersect, and for debate within Indigenous communities themselves about women's rights that may otherwise be obscured.

In Chapter 14, I relate the history of worldwide laws that, in the nineteenth and twentieth centuries, conditioned married women's nationality - and thus constitutional citizenship - upon the nationality of their husband, a practice that led to women's citizenship-stripping in cases of foreign marriage and gave rise to escalating statelessness among women in the inter-war years. I describe the international community's long adherence to this practice, with its final repudiation in the 1957 United Nations Convention on the Nationality of Married Women. As I explain, although conditional marital nationality laws have now almost disappeared, women's equal citizenship/nationality is still unrealized in many countries in the world, in particular where mothers are unable to transmit their nationality to their children on equal terms with fathers. Women's unequal access to constitutional citizenship remains a matter of global concern.

Part V, 'Constitutional Challenges', begins with Susan Williams's discussion (Chapter 15) of the challenge posed by legal pluralism for constitutional drafters and reformers concerned with gender equality. Williams identifies ways of organizing the disparate literatures on gender equality and legal pluralism into a 'single landscape', creating a typology of approaches that can help identify particular legal issues and mechanisms for addressing gender equality. Williams approaches these issues through her experience as an advisor on constitutional reform in Liberia, Burma/Myanmar and Libya. She concludes that clashes between cultural values and gender equality principles are best resolved through cultural development rather than legal or political coercion. 
Rosalind Dixon and Jade Bond, in Chapter 16, discuss the constitutional protection of women's reproductive rights through an exploration of landmark cases on abortion in constitutional courts in the United States, Canada, Germany and Colombia. They explain how the diversity of approaches reflected in these cases in their different political contexts has nevertheless produced a convergence that is exceptional in world terms, raising questions about the effect of the constitutionalization of abortion rights, including the key question (with broader implications for constitutional regulation of social and political conflict) of why constitutions came to be implicated in such issues in the first place.

In Chapter 17, Katharine Gelber and Adrienne Stone consider the particular challenges created for gender equality by the constitutional protection of freedom of speech/expression, focusing on questions surrounding the regulation of pornography and the clash of views about pornography's compatibility with gender equality. They consider key cases in the United States, the United Kingdom and Canada, as well as feminist debates about the link between pornography and the oppression of, or violence against, women. They ask why feminist attention has been directed less towards understanding the harm produced by gender hate speech (analogous to race hate speech) than by pornography, and why there are relatively few laws directed at the first. This field, they conclude, is 'crying out' for further attention, and offering a 'new and promising forum for the continuing engagement between feminist thought and constitutional law'.

Chapter 18, by Beth Goldblatt, considers the particular relationship between women's inequality and social and economic conditions, and discusses the gendered character of constitutional protection of social and (especially) economic rights and their impact specifically upon women. Goldblatt notes women's particular susceptibility to poverty, their special health needs and their vulnerability to violence. She considers the origins and evolution of international rights and their impact on national constitutions, and she identifies five constitutional mechanisms for claiming women's social and economic rights, drawing on studies of South Africa, Colombia, Argentina, India, Canada, Uganda and the Netherlands, among others. Goldblatt observes that there is a rich and diverse constitutional jurisprudence on gender and social and economic rights, as well as examples of non-constitutional legal and institutional mechanisms directed to these rights. Constitutional rights, she concludes, are not the only mechanism for achieving relevant change, but they need to be extended through interpretation and application, a current challenge for theorists and courts. 
John Kang closes the collection, in Chapter 19, with a reminder both that 'gender' is not just about women and that constitutions can be unwritten, offering an intriguing historical account of the 'patriarchal' character of the British monarchy against which the American revolutionaries and constitution-makers rebelled, only to maintain a patriarchal system of dominance over women and slaves. Kang brings his account into the twentieth century, describing the American imposition of a post-war constitution on Japan, with an analysis of the anxiety captured by its framers about Japanese patriarchal masculinity.

These chapters range widely and their subjects reveal the broad scope of the field, but they neither claim to represent, nor could they, all there is to say about constitutions and gender. The field is still young and emerging. Many perspectives remain to be identified and questions to be asked. Even the scope and identity of the 'constitutional', itself, remain open. This Handbook has focused principally, although not exclusively, on constitutions as written instruments, legal documents that describe themselves expressly as 'constitutions' and serve as foundations for state polities and legal systems. But, in a broader, systemic sense, the 'constitutional' embraces all institutions of government and all the rules - written and unwritten, formal and informal, legal and cultural - that structure the organization of society. These extend to the institutions of civil society that also operate within or alongside those of the state: political parties, religious bodies, the corporate sector, economic and financial institutions, educational institutions and even family relationships.

A full understanding of the way in which gender (and sex) are 'constituted' and difference and inequalities are constitutionally structured and embedded, would embrace all these institutions, and more. It would also be voluminous and probably unachievable. More significantly, it would obscure the singularity of constitutions (extending to charters of rights) in their formal sense as foundational, enforceable and powerful instruments.

With this in mind, what further directions might a study of constitutions and gender take? What subjects have potential to be explored, but have not yet been examined sufficiently for inclusion in this particular volume? Several come to mind. For example, what difference, if any, does the constitutional system of civil law countries make compared to that of common law countries in addressing gender inequalities? Or the difference between presidential and parliamentary constitutional systems? Or monarchies and republics? How, if at all, are gender differences reflected in processes and outcomes of constitutional amendment? What about the design of and impact on women of constitutional compliance bodies such as Human Rights Commissions, Ombudsmans or 
Commissions for Gender Equality (such as mandated by the South African Constitution)? Is there a discernible 'gendered' difference between 'strong-form' and 'weak-form' judicial review (Tushnet 2003)? Many 'gender-and' topics also present themselves: constitutional recognition of marriage; protection of religious freedom; the role of women in the military forces; women and national security regimes; 'constitutional identity' theory, and much more.

Nevertheless, despite the many questions yet to be addressed, as will be clear from the chapters, there are sufficient commonalities across constitutional systems for a coherent comparative perspective, and enough for us to be confident that the relationship between constitutions and gender is not fanciful. We can also see the transnational potential for constitutions as transformative instruments - either in themselves or as reflections of pre-existing transformations (that particular chicken-andegg issue remains to be resolved).

We can be confident too, whatever the case, that the gendered nature of constitutions is an insight that is here to stay, and that women will not abandon their commitment to participating and being recognized in constitution-making and its outcomes. It is a measure of how far this insight has already come that it is simply obvious that constitutionmaking or reform cannot claim democratic legitimacy without the voice of half (often more than half) the population: that '[the] need for legitimation dictates that a democratic constitution must be fashioned by democratic means in acknowledgment of the moral claim of a people to the right to participate in the creation of the rules under which they will be governed' (Blount 2011: 38). The disenfranchisement or exclusion of women from these processes (including in their contemplation and planning) is simply incompatible with this democratic imperative. Democracy demands that women's voices be heard, on terms of equality, in and about the design and content of their country's foundational document. The chapters in this Handbook are a further demonstration that these voices have resonance, and their expression is not merely procedural, but also advances our understanding of the nature, sources and objects of constitutional power.

\section{NOTES}

1. United States v Susan B. Anthony (1873); Bradwell v State of Illinois, 83 U.S. 130 (1873); Minor v Happersett, 88 U.S. 162 (1875).

2. For example, in a 2009 law review symposium, entitled 'What, if Anything Do We Know about Constitutional Design?', Texas Law Review (2009) 87: 1265, neither the introduction nor any of the 13 contributions mentions women or gender. 


\section{Constitutions and gender}

3. 404 U.S. 71 (1971).

4. See http://constitutions.unwomen.org/en.

5. See http://www.constituteproject.org/?lang=en (accessed 12 October 2016).

6. See http://www.idea.int/about/index.cfm (accessed 12 October 2016).

7. Compare, for example, Tom Ginsburg (ed.) (2012), Comparative Constitutional Design, Cambridge University Press, with Donald S. Lutz (2006), Principles of Constitutional Design, Cambridge University Press.

8. Shelmon, Brittany (2016), 'Pathways to Leadership: Four Women's Journeys to the Peace Negotiation Table in the Fight for Democracy in Burma', Indiana Journal of Constitutional Design: Vol. 1, Article 2. Available at: http://www.repository.law. indiana.edu/ijcd/vol1/iss1/2.

\section{REFERENCES}

Amar, Akhil Reed (1995), 'Women and the Constitution', Harvard Journal of Law and Public Policy 18: 465.

Aung, Thin and Susan H. Williams (2009), 'Women in the Constitutional Drafting Process in Burma', in Susan H. Williams, Constituting Equality: Gender Equality and Comparative Constitutional Law, Cambridge University Press.

Baines, Beverley and Ruth Rubio-Marín (eds) (2005), The Gender of Constitutional Jurisprudence, Cambridge University Press.

Blount, Justin (2011), 'Participation in Constitutional Design', in Tom Ginsburg and Rosalind Dixon (eds), Comparative Constitutional Law, Edward Elgar.

Brodsky, Gwen and Shelagh Day (1989), Canadian Charter Equality Rights for Women: One Step Forward or Two Steps Back?, Canadian Advisory Council on the Status of Women.

De Pauw, Linda Grant (1975), Founding Mothers: Women in America in the Revolutionary Era, Houghton Mifflin.

Dobrowlosky, Alexandra and Vivien Hart (eds) (2003), Women Making Constitutions: New Politics and Comparative Perspectives, Palgrave Macmillan.

Elson-Roessler, Shirley (1996), Out of the Shadows: Women and Politics in the French Revolution, P. Lang.

Ginsburg, Ruth Bader (1975), 'Gender and the Constitution', Cincinnati Law Review, 44(1): 1 .

Ginsburg, Ruth Bader (1978), 'Sex Equality and the Constitution', Tulane Law Review, 52(3): 451.

Goldfarb, Sally (2003), 'The Supreme Court, the Violence Against Women Act, and the Use and Abuse of Federalism', Fordham Law Review 71: 57.

Gordon, Beate Sirota (2001), The Only Woman in the Room, Kodansha International.

Heuer, Jennifer Ngaire (2005), The Family and the Nation: Gender and Citizenship in Revolutionary France, 1789-1830, Cornell University Press.

Irving, Helen (2011), 'Drafting, Design and Gender', in Tom Ginsburg and Rosalind Dixon (eds), Comparative Constitutional Law, Edward Elgar.

Irving, Helen (2008), Gender and the Constitution: Equity and Agency in Comparative Constitutional Design, Cambridge University Press.

Irving, Helen (1999), To Constitute a Nation: A Cultural History of Australia's Constitution, Cambridge University Press, Chapter 10, 'Half the Nation'.

Jackson, Vicki C. (2009), 'Gender Equality and the Idea of a Constitution: Entrenchment, Jurisdiction and Interpretation', in Susan H. Williams (ed.), Constituting Equality: Gender Equality and Comparative Constitutional Law, Cambridge University Press. 
Kome, Penney (1983), The Taking of Twenty-Eight: Women Challenge the Constitution, Women's Press.

Liebenberg, Sandra (ed.) (1995), The Constitution of South Africa from a Gender Perspective, Community Law Centre, University of the Western Cape.

Markovits, Inga (2008), 'Constitution Making after National Catastrophes: Germany in 1949 and 1990', William \& Mary Law Review 49: 1307.

Monopoli, Paula A. (2006), 'Gender and Constitutional Design', Yale Law Journal 115: 2643.

Morais, Nina (1988), 'Sex Discrimination and the Fourteenth Amendment: Lost History', Yale Law Journal 97: 1153.

Norton, Mary Beth (1996), Founding Mothers and Fathers: Gendered Power and the Forming of American Society, Alfred A. Knopf.

O'Regan, Kate and Nick Friedman (2011), 'Equality', in Tom Ginsburg and Rosalind Dixon (eds), Comparative Constitutional Law, Edward Elgar.

Resnik, Judith (2002), 'Categorical Federalism: Jurisdiction, Gender and the Globe', Yale Law Journal 11: 619.

Roberts, Cokie (2004), Founding Mothers: The Women Who Raised Our Nation, William Morrow.

Rose, Kenneth D. (1996), American Women and the Repeal of Prohibition, New York University Press.

Rubenstein, Kim and Katharine G. Young (eds) (2016), The Public Law of Gender: From the Local to the Global, Cambridge University Press.

Schwarzenbach, Sibyl A. and Patricia Smith (eds) (2003), Women and the United States Constitution, Columbia University Press.

Sharpe, Robert and Patricia McMahon (2007), The Persons Case: The Origins and Legacy of the Fight for Legal Personhood, University of Toronto Press.

Smith, Lynne and Eleanor Wachtel (1992), A Feminist Guide to the Canadian Constitution, Canadian Advisory Council on the Status of Women.

Sullivan, Kathleen (2002), 'Constitutionalizing Women's Equality', California Law Review 90: 735 .

Tushnet, Mark (2003), 'Alternative Forms of Judicial Review', Michigan Law Review 101: 2781.

Van der Leest, Kristin (2007), 'Engendering Constitutions: Gender Equality Provisions in Selected Constitutions', Unifem.

Williams, Susan H. (ed.) (2009), Constituting Equality: Gender Equality and Comparative Constitutional Law, Cambridge University Press.

Young, Katharine G. (2016), 'Introduction: A Public Law of Gender?', in Kim Rubenstein and Katharine G. Young (eds), The Public Law of Gender: From the Local to the Global, Cambridge University Press. 
Helen Irving - 9781784716967 Downloaded from PubFactory at 04/26/2023 12:46:17PM via free access 